\title{
Phytochemical Composition and Pleotropic Pharmacological Properties of Jamun, Syzygium Cumini Skeels
}

\author{
Ganesh Chandra Jagetia* \\ Department of Zoology, Mizoram University, Aizawl-796004, India
}

\begin{abstract}
Plants have been employed as medicine since time immemorial, and there has been a recent resurgence in the use of plants as medicines due to their little or no toxicity at the doses used for treatment of different ailments. This review discusses in detail the phytochemical and pharmacological activities of Jamun (Syzygium cumini), a tree belonging to family Myrtaceae, which has been credited with several medicinal properties in the traditional system of medicine, the Ayurveda. The different properties attributed to Jamun are sweet, sour, astringent, acrid, refrigerant, carminative, diuretic, and digestive. Research and practical use in traditional medicinal systems have found Jamun to be effective in treating leucorrhoea, gastric disorders, fever, diabetes, piles, stomachache, wounds, and dental, digestive and skin disorders. Some compounds in Jamun have antioxidant, antimicrobial, antiallergic, antidiabetic, antihyperlipidemic, anticancer, gastroprotective, hepatoprotective, cardioprotective and radioprotective activity. Finally, Jamun has been found to contain phytochemicals including anthroquinones, alkaloids, catechins, flavonoids, glycosides, steroids, phenols, tannins, saponins and cardiac glycosides. The diverse activities of Jamun may be due to its abilities to scavenge free radicals, increase antioxidant status of cells by increasing glutathione, glutathione peroxidase, catalase and/or superoxide dismutase, and to attenuate lipid peroxidation. In addition, it also suppresses the transcription of peroxisome proliferator-activated receptor, Nuclear factor kappa B, cyclooxygenase, inducible nitric oxide synthase, tumor necrosis factor alpha and other proinflammatory cytokines, accompanied by the up-regulation of nuclear factor erythroid 2-related factor 2 transcription, which is involved in regulating the antioxidant status of the cells.
\end{abstract}

\section{Introduction}

Taxonomically, Jamun belongs to Kingdom: Plantae; Division: Magnoliophyta; Class: Magnoliopsida; Order: Myrtales; Family: Myrtaceae; Genus: Syzygium and Species: cumini. It is also known by the other names of Syzygium jambolana (Lam.) DC, Syzygi-

Keywords: Jamun; Medicine; Antioxidant; Antidiuretic; Radioprotective; Antihyperlipidemic

Abbreviations: PPAR, peroxisome proliferator-activated receptor; NF- $\kappa \mathrm{B}$, Nuclear factor kappa B; COX, cyclooxygenase; iNOS, inducible nitric oxide synthase; TNF $\alpha$, tumor necrosis factor alpha; Nrf2, nuclear factor erythroid 2-related factor 2; NO, Nitric Oxide; $\mathrm{OH}$, Hydroxyl; DPPH, 2,2-diphenyl-1-picrylhydrazyl; $\mathrm{O}_{2}^{-} \bullet$, superoxide; FRAP, ferric reducing power; ABTS, 2,2'-azino-bis(3-ethylbenzothiazoline-6-sulphonic acid; DCM-MET, dichloromethane and methanol; HDL-c, high density lipoprotein cholesterol; LDL-c, low density lipoprotein cholesterol; GSH, glutathione; SOD, superoxide dismutase.

Received: December 27, 2016; Revised: April 28, 2017; Accepted: May 02, 2017

${ }^{*}$ Correspondence to: Ganesh Chandra Jagetia, Department of Zoology, Mizoram University, Aizawl-796 004, India. Tel: 91-0389-2330724; 2330227, E-mail: gc.jagetia@gmail.com

How to cite this article: Jagetia GC. Phytochemical Composition and Pleotropic Pharmacological Properties of Jamun, Syzygium Cumini Skeels. J Explor Res Pharmacol 2017;2(2):54-66. doi: 10.14218/JERP.2016.00038 um jambolanum DC, Syzygium caryophyllifolium (Lam.) DC, Calyptranthes oneillii Lundell, Calyptranthes jambolana Willd., Eugenia cumini Druce, Eugenia caryophyllifolia Lam., Eugenia jambolana Lam., Eugenia djouat Perr., and Myrtus cumini L (Fig. 1). It is native to the Indian subcontinent, and is widely distributed throughout India, Pakistan, Bangladesh, Myanmar and Ceylon. However, Jamun has been introduced into different parts of the world, including the United States of America, for its economic importance as a producer of fruits and timber.

Jamun is a fast growing tree that reaches heights up to 100 feet, and it bears fruits in clusters during the summer. Each fruit cluster may contain fruits numbering only a few to as many as 10 or even 40. The Jamun fruits are round to oblong in shape, with the size of each varying between $1 / 2$ to 2 inches (Fig. 1). They are green in color and turn from light to dark purple, or even black coloration, once they are fully ripe. ${ }^{1}$ The taste of the Jamun fruits is sweetish sour, and eating of the fruits tends to color the tongue purple.

The Jamun tree is considered sacred by Hindus and Buddhists, alike, and is commonly found in the compounds of Hindu temples. It is considered dear to Lord Krishna and its leaves and fruits are offered to Lord Ganesha (Elephant God) during his worship. ${ }^{2}$ The Jamun tree is also known by other names across the globe, such as black plum, Indian blackberry, Jaman, Jambu, Jambul, Jambool, 
A

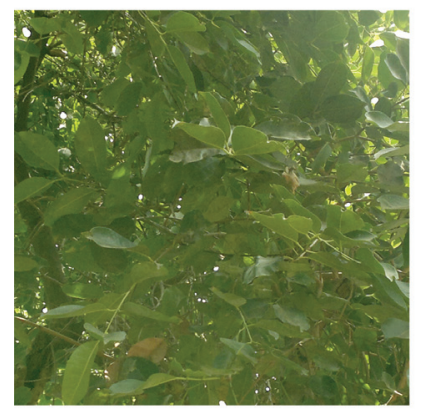

C

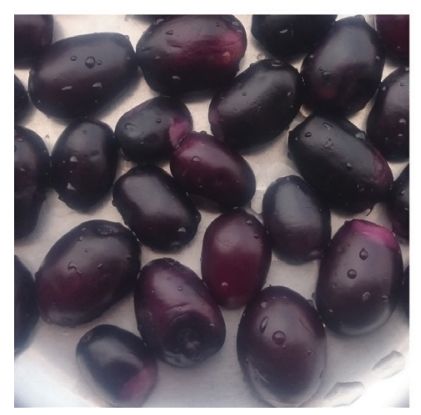

B

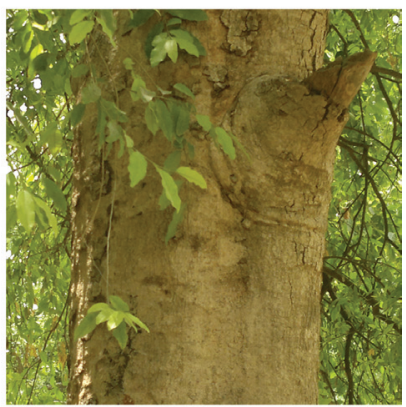

D

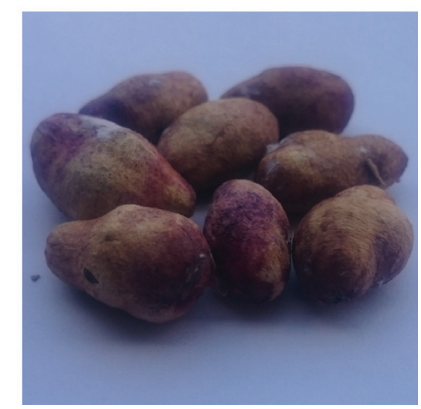

Fig. 1. Different parts of Jamun, Syzygium cumini. a: leaves; b: stem; c: fruit; d: seed.

Java plum, Malabar plum, Duhat and Portuguese plum..$^{3,4}$

\section{Traditional medicinal uses}

Plants have been used by humans for healthcare since the advent of human history, and they are still used by the majority of the population due to their non-toxic nature and economic affordability. However, the scientific basis of use of these medicinal plants still needs to be validated. Jamun is one of the medicinal plants that have been used in diverse traditional ethnomedicinal practices to treat various disorders in humans. ${ }^{5}$ Jamun's most common uses have included diabetes and in dental, digestive, liver and skin disorders.

In Ayurvedic medicine, 1-3 g of dried seed powder is usually given orally to humans to treat diabetic conditions. Different parts of Jamun have been used to cure blisters in the mouth, colic, digestive complaints, diarrhea, dysentery, diabetes, pimples, piles, stomachache, and cancer. ${ }^{6}$ Juice of the ripened fruit is administered in the dose range of $0.5-2$ teaspoons $(2.5-10 \mathrm{~mL})$ thrice a day to treat diabetes in humans. ${ }^{7,8}$ Jamun is also considered a good general health tonic for humans, acting as a blood purifier. The Jamun stem bark is used as an astringent, anthelmintic, antibacterial, carminative, constipating, diuretic, digestive, febrifuge, refrigerant, stomachic and sweet. The fruits and seeds are used to treat asthma, diabetes, bronchitis and splenopathy.,10 Fresh Jamun fruit pulp with honey is administered to keep the body healthy, while its seed powder is given to help in clearing the skin blemishes left by blackheads and acne. The fruit juice is also useful for treating enlarged spleen and resolving urinary problems. ${ }^{11}$ Jamun seed powder mixed with jaggery provides relief in diarrhea and dysentery. The leaf juice and poultice of the leaves are effective in the treatment of dysentery and skin disorders. ${ }^{12,13}$ Moreover,

the application of Jamun leaf ash cures bleeding gums and keeps teeth healthy, ${ }^{8}$ while the leaf paste is a good general wound healing agent.

In Unani medicine, Jamun is used as a liver tonic. And, similar to its application in Ayurvedic medicine, Jamun is known in Unani medicine to strengthen teeth and gums, enrich blood, and deworm against ringworm infection of the head. ${ }^{14}$ The Jamun fruit pulp is also used to treat gingivitis, and application of Jamun for 2-4 months is helpful in treating hemorrhoids.

The Jamun stem bark, dried seeds and root bark decoction is used to treat diarrhea, dysentery and dyspepsia, and it can also act as an enema. ${ }^{13}$ Stem bark powder mixed with yoghurt is given to treat menorrhagia, ${ }^{7}$ and when mixed with Jamun fruit juice cures cough and cold. In addition, one glass of Jamun fruit juice with half teaspoon of stem bark powder given daily relives the problems of urinary tract disorders and urinary infections. In India, the Jamun seed powder is used as an antidote against strychnine poisoning. ${ }^{12}$ The decoction of the Jamun stem bark is used to cure asthma and bronchitis. ${ }^{15}$ When the stem bark decoction is gargled or used as a mouthwash it can cure mouth ulcerations, spongy gums and stomatitis. ${ }^{11,13}$ The stem bark ashes of Jamun can either be mixed with water and used as a general anti-inflammatory agent, or mixed with oil and used to treat burns. ${ }^{11}$ Seed decoction of Jamun relieves fatigue and strain.

Research into the traditional uses of Jamun has encompassed investigations into the application of all different parts of the Jamun plant by means of various study systems, with the aim of substantiating the claims of traditional healers and harnessing its diverse medicinal properties for evidence-based modern clinical practice.

\section{Phytochemical analysis}

The medicinal properties of Jamun may be due to its ability to synthesize various phytochemicals. Indeed, many investigators have studied the phytochemical profiles of Jamun roots, stem, leaves and fruits, and their findings are detailed in this section.

The leaves of Jamun have been extracted in methanol and water, and analyzed for the presence of different phytochemicals. Both aqueous and methanol extracts have been found to possess a range of alkaloids, flavonoids, glycosides, steroids, phenols, tannins, saponins and cardiac glycosides. ${ }^{16,17}$ Meanwhile, the ethanol stem bark extracts of Jamun have shown the presence of terpenoids, alkaloids, catechins, phenols, quinones, saponins and tannins, whereas, the methanol extract of such was found to additionally contain flavonoids. On the other hand, the aqueous stem bark extract only contained catechins, phenols, quinones and flavonoids. ${ }^{18}$ Likewise, the ethyl acetate and methanol extracts of Jamun seeds were found to contain flavonoids, alkaloids, glycosides, triterpenoids, steroids, saponins, and tannins. ${ }^{19}$

Different leaf extracts of Jamun have been tested for the presence of various phytochemicals, and the methanol, ethanol and aqueous extracts of leaves were found to contain flavonoids, anthroquinones, tannins, phenols, steroids. All except the aqueous extract contained alkaloids. The analysis of chloroform and petroleum ether extracts showed the presence of flavonoids anthroquinones and steroids, but a striking absence of tannins, terpenoids, saponins, phenols and alkaloids. The cardiac glycosides were absent in all the extracts of Jamun leaf reported. ${ }^{20}$

The phytochemical analysis of ethanol extract of Jamun stem bark, leaf, seed and fruit pulp showed the presence of alkaloids, anthroquinone glycosides, flavonoids, tannins, saponins, phenols, cardiac glycosides, terpenoids, phytosterols, steroids and amino 
<smiles>COc1c(O)cc2c(c1O)C1OC(CO)[C@@H](O)C(O)C1OC2=O</smiles>

Bergenin

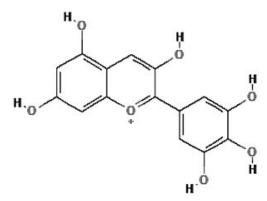

Delphinidin<smiles>COc1ccc(C2Oc3cc(O)cc(O)c3C(=O)C2=O)cc1</smiles>

Kaempferol

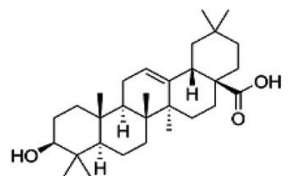

Malvidin<smiles>COc1cc(-c2cc(O)cc3c(O)cc(O)cc23)cc(O)c1O</smiles>

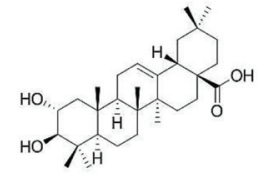

Crategolic acid<smiles>O=c1oc2c(O)c(O)cc3c(=O)oc4c(O)c(O)cc1c4c23</smiles>

Ellagic acid<smiles>C[C@@H]1O[C@H](O)[C@H](O)[C@H](N(C)C)[C@@H]1O</smiles>

Mycaminose<smiles>O=c1c(O)c(-c2ccc(O)c(O)c2)oc2cc(O)cc(O)c12</smiles>

Quercetin

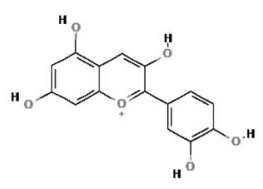

\section{Cynidin}<smiles>COc1cc(C(=O)O)cc(OC)c1O</smiles>

Gallic acid<smiles></smiles>

Myricetin

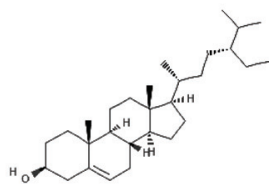

$\beta$-sitosterol

Fig. 2. Chemical structures of some important phytochemicals present in different parts of Jamun, Syzygium cumini.

acids in all extracts, with the exception that anthroquinones were absent in the seed and pulp extracts, whereas terpenoids and phytosterols were absent in the leaf extract. ${ }^{21}$

\section{Active components}

The different parts of Jamun have been subjected to isolation and characterization of various types of phytochemicals. including the flavonoids, phenolic acids, terpenes, tannins and anthocyanins (Fig. 2). The leaves of Jamun were found to contain betulinic acid, crategolic acid, n-dotricontanol, n-hentriacontane, n-hepatcosane, mycaminose, myricetin, myricitrin, myricetin 3-O-(4"-acetyl)$\alpha$-L-rhamnopyranosides, $n$-nonacosane, quercetin, $\beta$-sitosterol, noctacosanol, n-triacontanol, triterpenoids, tannins, eicosane, octacosane and octadecane. ${ }^{1,22-25}$ The essential oils from Jamun leaves showed the presence of $\alpha$-cadinol, geranyl acetone, muurolol, $\alpha$-myrtenal, pinocarvone, pinocarveol, a-terpeneol, myrtenol, eucarvone, cineole, alloocimene, $\alpha$-bornyl acetate, $\alpha$-pinene, 2 - $\beta$-pinene, caryophyllene, caryophyllene oxide, L-limonene, $\alpha$-humulene, $\alpha$-terpineol and $\alpha$-terpineolene. ${ }^{26-28}$

The flowers of Jamun have shown the presence of various phytochemicals, including kaempferol, quercetin, myricetin, isoquercetin (quercetin-3-glucoside), myricetin-3-L-arabinoside, quercetin-3-Dgalactoside, dihydromyricetin, oleanolic acid, acetyl oleanolic acid, eugenol-triterpenoid A and eugenol-triterpenoid B. ${ }^{29}$

The fruit of Jamun consists of different anthocyanins (including delphinidin 3,5-diglucoside, cyanidin 3,5-diglucoside, petunidin 3,5-diglucoside, peonidin 3,5-diglucoside, delphinidin 3-glucoside, malvidin 3,5-diglucoside, delphinidin acetyl-diglucoside, peonidin-3,5-diglycoside, petunidin 3-glucoside, malvidin 3-glucoside), non-anthocyanic phenolic compounds [such as galloyl-glucose ester, ellagic acid and gallic acid (phenolic acid)], and flavanols (such as dihydroquercetin diglucoside, dihydromyricetin diglucosidemethyl-dihydromyricetin, diglucoside, dimethyl-dihydromyricetin diglucoside, myricetin glucoside, myricetin pentoside, myricetin rhamnoside , myricetin acetyl-rhamnoside and myricetin). ${ }^{30-32}$ The fruit pulp also includes cyanidin 3-glucoside, cyanidin 3-rutinoside, cyanidin 3-xyloside, cyanidin 3-malonylglucoside, cyanidin 3-dioxalylglucoside, quercetin 3-rutinoside, quercetin 3-galactoside, quercetin 3-glucoside, quercetin 3-glucuronide, quercetin 3-O-[600-(3-hydroxy-3-methylglutaroyl)]- $\beta$-galactoside, quercetin 3-glucosylpentoside, quercetin 3-oxalylpentoside, quercetin 3-rhamnoside, quercetin, lambertianin $\mathrm{C}$ isomer, sanguiin $\mathrm{H}-6$ lambertianin A and galloyl-bis-HHDP glucose isomer. ${ }^{28,33}$

The seeds of Jamun have been reported to include 7-hydroxycalamenene, methyl- $\beta$-orsellinate, $\beta$-sitosterol, and oleanolic acid, and 3-hydroxy androstane [16,17-C](6'methyl, 2'-1-hydroxy isopropene-1-yl) 4,5,6 $\mathrm{H}$ pyran. ${ }^{34}$ The methanol extract of Jamun seeds showed the presence of 34 chemicals, principle among them being 5,10-dichloro-5,10-dimethyltricyclo[7.1.0.0(4,6)]decane, tetradecanoic acid, $\alpha$-caryophyllene, 1,10 -decandiol, $\beta$ caryophyllene, bicyclo(4.4.O)decane, octadienol, cadinene, 4-dodecen-1-ol acetate, 2-furancarboxaldehyde 5-(hydroxymethyl) and oxirane 2,3-dimethyl. The ethanol extract showed presence of caryophyllene oxide, bicyclo(7.2.0)undec-4-ene, 4,11,11-trimethyl-8-methylene, 


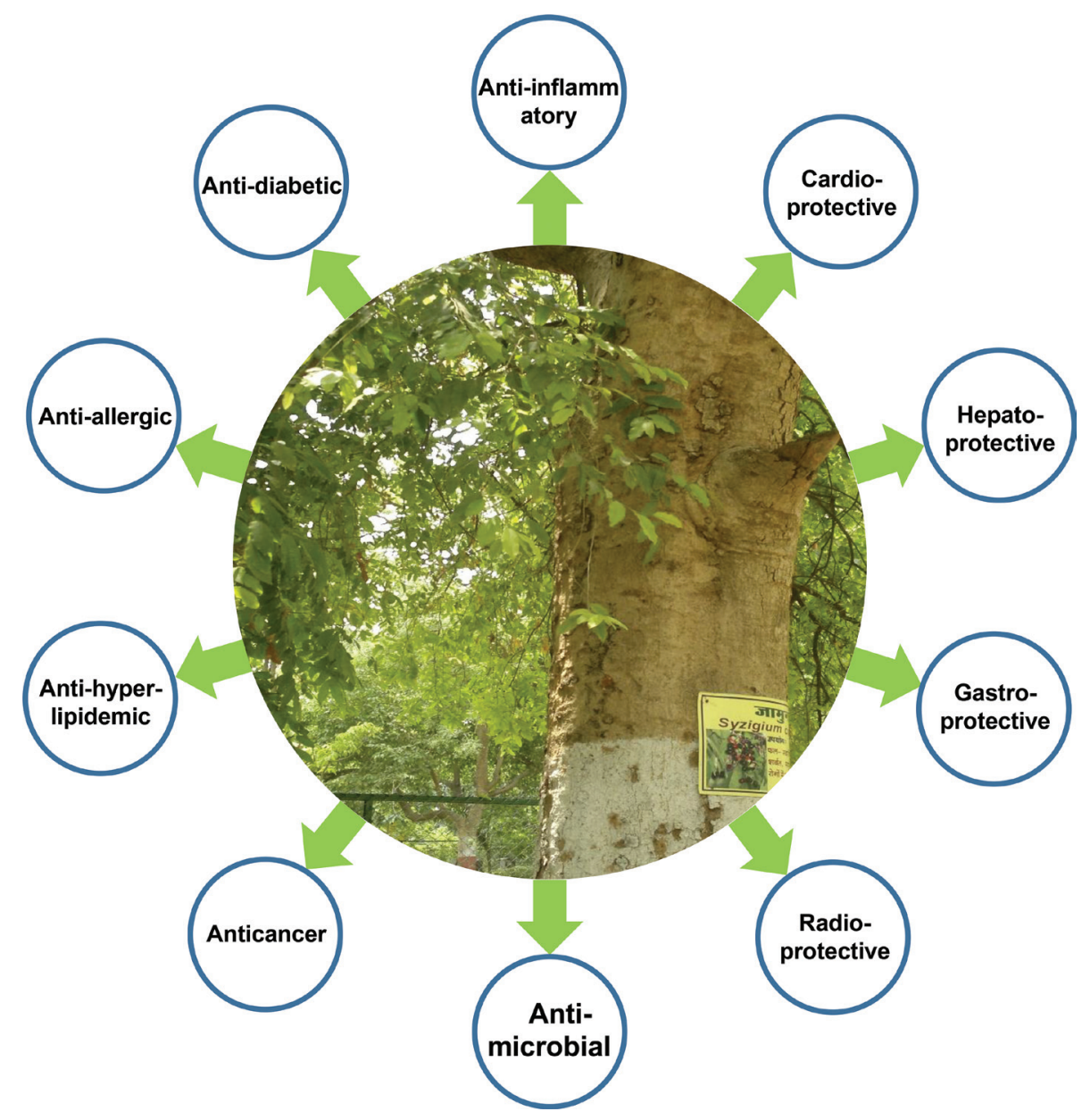

Fig. 3. Different activities of various parts of Jamun, Syzygium cumini.

5(hydroymethyl)-2-furaldehyde, isogeraniol, 3(2H)-furanone dihydroxy-2-methyl, decahydro-4A-methyl-1-methylene-7-(1methylethenyl), 12-methyl-E,E-2,13-octadecadien-1-ol, nondecanoic acid, guaiol, limonene oxide, 2-methyl-3-isobutenyl-4-penten-2-ol, 3-methyl-4-hexyn-3-ol,thujanol and 10-undecyn-1-ol. ${ }^{35}$

The stem bark has been found to contain betulinic acid, friedelin, epi-friedelanol, $\beta$-sitosterol, eugenin and fatty acid ester of epifriedelanol. ${ }^{36} \beta$-sitosterol, quercetin kaempferol, myricetin, gallic acid and ellagic acid, bergenins, flavonoids and tannins have also been reported from the stem of Jamun. ${ }^{37-39}$

\section{Antioxidant activity}

Various parts of Jamun have been shown to exert antioxidant activity, as indicated by free radical scavenging assays. Moreover, the Jamun leaf and seed extracts have shown a concentration-dependent increase in the scavenging activity of nitric oxide (NO) free radicals. ${ }^{40}$ The aqueous extract of Jamun fruit skin has been found to scavenge hydroxyl $(\mathrm{OH})$, superoxide $\left(\mathrm{O}_{2}^{-} \bullet\right)$ and DPPH free radicals. ${ }^{41}$

The DPPH radical scavenging and ferric-reducing power (FRAP) of leaf extract were evaluated in the methanol extract and its fraction of ethyl acetate, chloroform, n-hexane and water. The ethyl acetate fraction was found to be most potent in scavenging of
DPPH radicals and FRAP. ${ }^{42}$ The anthocyanin-rich extract prepared in acidified $\left(5 \% \mathrm{H}_{3} \mathrm{PO}_{4}\right)$ ethanol from Jamun fruits was shown to scavenge 2,2'-azino-bis(3-ethylbenzothiazoline-6-sulphonic acid) (ABTS) anion and peroxy radicals efficiently. ${ }^{31}$

The 1:1 dichloromethane and methanol (DCM-MET) extract of Jamun leaves was evaluated for its ability to scavenge different free radicals in vitro. The Jamun extract was found to scavenge $\mathrm{OH}$ free radicals in a dose-dependent manner and maximum effect was achieved with $350 \mu \mathrm{g} / \mathrm{mL}$. This extract also inhibited the generation of $\mathrm{O}_{2}^{-} \cdot$ radicals, and the greatest effect was achieved with $250 \mu \mathrm{g} / \mathrm{mL}$. Similarly, it equally inhibited DPPH and $\mathrm{ABTS}^{+}$ free radicals, and the highest effect was achieved with $80 \mu \mathrm{g} / \mathrm{mL}$ for both radicals. ${ }^{43}$

The acid ethanol extracts of seed and fruit pulp of Jamun have been reported to inhibit generation of DPPH and $\mathrm{ABTS}^{+}$free radicals, and to exhibit iron chelating activity. ${ }^{44}$ The aqueous leaf extract of Jamun was shown to scavenge $\mathrm{OH}, \mathrm{O}_{2}^{-} \cdot$, NO and $\mathrm{ABTS}^{+}$. free radicals in a concentration-dependent manner. ${ }^{45}$ The methanol, and methylene chloride extracts of Jamun leaves and its oils have been reported to scavenge DPPH radicals and increase the FRAP. ${ }^{46}$ The studies on methanol and aqueous leaf extracts of Jamun have also revealed an ability to inhibit the generation of $\mathrm{OH}, \mathrm{NO}$, and DPPH free radicals in a concentration-dependent manner and to cause an increase in the FRAP with increasing concentrations. ${ }^{47}$

The above-mentioned DPPH radical scavenging and FRAP 
Table 1. Antiinflammatory and antiallergic activities of Jamun, Syzygium cumini

\begin{tabular}{|c|c|c|c|c|c|}
\hline S. No. & Parts used & Extract type & Activity & Species & References \\
\hline \multirow[t]{3}{*}{1.} & \multirow[t]{3}{*}{ Seed } & Chloroform & Anti-inflammatory & Rat & {$[55]$} \\
\hline & & Methanol \&ethyl acetate & & Rat & [58] \\
\hline & & Aqueous & & Human & {$[56]$} \\
\hline 2. & Stem bark & Ethanol & & Rat & [57] \\
\hline \multirow[t]{3}{*}{3.} & \multirow[t]{3}{*}{ Leaf } & Methanol & & Rat & [59] \\
\hline & & Essential oil & & $\begin{array}{l}\text { Rat } \\
\text { Mice }\end{array}$ & $\begin{array}{l}{[60]} \\
{[61]}\end{array}$ \\
\hline & & Aqueous & & Mice & [45] \\
\hline 4. & Flavonoid fraction & - & & Human & {$[62]$} \\
\hline 5 & Root & Aqueous & & $\begin{array}{l}\text { RAW } 264.7 \\
\text { macrophages }\end{array}$ & {$[54]$} \\
\hline \multirow[t]{2}{*}{6} & Leaf & Aqueous & Antiallergic & Mice & [63] \\
\hline & Root & $\begin{array}{l}\text { Aqueous } \\
\text { Methanol }\end{array}$ & & Mice & [64] \\
\hline
\end{tabular}

study revealed that the ethanol seed extract was the most potent, followed by stem bark and leaf extracts of Jamun. ${ }^{21}$ In another study, the methanol leaf extract was shown to increase the FRAP with increasing concentration and demonstrated its superiority to fruit pulp and seed extracts. ${ }^{48}$

\section{Antibacterial and antifungal activity}

Essential oils extracted from the Jamun leaves have been reported to exert antibacterial properties against Basillus sphaericus, Basillus sphaericus, Staphylococcus aureus, Escherichia coli, Pseudomonas aeruginosa and Samonella typhimurium. ${ }^{26}$ The hydroalcoholic extract of Jamun leaves was found to be active against Candida krusei and antibiotic-resistant bacterial species of $P$. aeruginosa, Klebsiella pneumoniae and $S$. aureus in addition to Enterococcus faecalis, E. coli, Kocuria rhizophila, Neisseria gonorrhoeae, P. aeruginosa, and Shigella flexneri. ${ }^{49}$ The diethyl ether, methanol and aqueous extracts of Jamun fruit inhibited the growth of Bacillus cereus, Staphylococcus epidermidis, Micrococcus luteus and Salmonella typhi, respectively. ${ }^{50}$ The ethanol extract of Jamun leaf has been reported to be active against the Vibrio cholerae serogroups Ogawa and Inaba. ${ }^{51}$

The $70 \%$ ethanol extract of Jamun leaf, bark, pulp and seed showed a potent antimicrobial activity against various Gram-positive bacteria (including B. subtilis, B. cereus and $S$. aureus) and Gram-negative bacteria (including $S$. flexneri, P. aeruginosa and $V$. cholera). Comparison analysis showed that the leaf and bark extracts were more potent than the pulp and seed extracts. ${ }^{21}$ The ethanol extract of Jamun seeds was found to inhibit the growth of $E$. coli, B. subtilis, $P$. aeruginosa and $S$. aureus. ${ }^{52}$ The aqueous extract of Janum stem and leaf showed antibacterial activity against all strains of bacteria, including $S$. aureus, Staphylococcus saprophyticus, E. coli, P. aeruginosa and Proteus vulgaris, whereas the fruit extract was active against $P$. aeruginosa only and the maximum antifungal activity was recorded for Penicillium chrysogenum and Candida albicans. ${ }^{53}$

The methanol and methylene chloride leaf extracts and the essential oils from Jamun leaves exhibited antibacterial activity against both Gram-positive and Gram-negative bacteria, and the methanol extract was superior to the methylene chloride extract and leaf oil. ${ }^{46}$ The ethanol extract of Jamun roots was found to be active against $S$. aureus, S. epidermidis, E. coli, Streptococcus suis, Salmonella spp. and Corynebacterium diphtheriae. The root extract of Jamun was found to be more effective against Grampositive bacteria than Gram-negative bacteria. ${ }^{54}$

\section{Anti-inflammatory activity}

Jamun has been reported to act as an anti-inflammatory agent, reducing both acute and chronic inflammation (Fig. 3 and Table $\left.1^{45}, 54-64\right)$. The chloroform seed extract has been reported to inhibit carrageenan (acute), kaolin-carrageenan-induced paw edema in the rats and to also suppress protein exudates, leakage of dye in peritoneal inflammation, and leukocyte migration. ${ }^{55}$ Similarly, the aqueous seed extract was found to exert an anti-inflammatory effect against human neutrophils. ${ }^{56}$

Preclinical studies using animal models have shown that the ethanol extract of Jamun stem bark exhibits anti-inflammatory activity, as demonstrated in carrageenan (acute), kaolin-carrageenan (sub-acute) and formaldehyde (sub-acute)-induced paw edema, as well as cotton pellet granuloma (chronic) rat models. ${ }^{57}$ The methanol and ethyl acetate seed extracts have shown an antiinflammatory response in carrageenan-induced rat paw edema. ${ }^{58}$ The methanol extracts of Jamun leaves have also been shown to reduce acute and chronic inflammation in carrageenan, histamine and serotonin-induced rat paw edema and cotton pellet-induced rat granuloma studies. ${ }^{59}$ In another study, essential oils from the Jamun leaf inhibited the migration of rat eosinophils, indicating that Jamun leaf possesses anti-inflammatory activity. ${ }^{60}$

The aqueous leaf extract has also been reported to reduce indomethacin-induced inflammatory changes in the mice by reducing nitric oxide synthase (iNOS), tumor necrosis factor-alpha (TNF- $\alpha$ ) and cyclooxygenase (COX) enzymes. ${ }^{45}$ The essential oils from Jamun leaf have been reported to alleviate chronic granulomatous inflammation in BALB/c mice that had been intravenously infected with Mycobacterium bovis Bacillus Calmettte-Guerin. ${ }^{61}$ The fla- 
Table 2. Protective effect of Jamun, Syzygium cumini on different disorders

\begin{tabular}{|c|c|c|c|c|c|}
\hline S. No. & Parts used & Extract type & Activity & Species & References \\
\hline 1. & Leaf & Aqueous & Hepatoprotective & Rat & {$[66]$} \\
\hline 2. & Fruit & $\begin{array}{l}\text { Ethanol } \\
\text { Methanol }\end{array}$ & & $\begin{array}{l}\text { Rat } \\
\text { Rat }\end{array}$ & $\begin{array}{l}{[30]} \\
{[67,68]}\end{array}$ \\
\hline 3. & Seed & Ethanol & & Rat & [69] \\
\hline 4. & Stem & & Gastroprotective & Rat & [70] \\
\hline 5. & Seed & Ethanol & & Rat & {$[71,72]$} \\
\hline \multirow[t]{4}{*}{6.} & Seed & Methanol & Cardioprotective & Rat cardiomyocytes & {$[35,73,76]$} \\
\hline & & Ethanol & & Rat & [74] \\
\hline & & Powder & & Human & [75] \\
\hline & Leaf & Hydroalcoholic & & Rat & [77] \\
\hline
\end{tabular}

vonoid fraction of Jamun has been reported to alleviate inflammatory response in human lymphocytes, monocytes and neutrophils against the hepatitis B vaccine. ${ }^{62}$ The aqueous and ethanol extracts of Jamun root were shown to reduce IL-6 production in RAW 264.7 macrophages, indicating slight anti-inflammatory activity. ${ }^{54}$ The aqueous seed extract was found to exert anti-inflammatory activity in diabetic rats, as indicated by the suppression of ectonucleotidase, adenosine deaminase, acetyl cholinesterase, dipeptidyl peptidase IV and NO activities. ${ }^{65}$

\section{Antiallergic activity}

The antiallergic effect of aqueous leaf extract of Jamun has been investigated in mice that had been injected with the mast-cell degranulator $\mathrm{C} 48 / 80$ or with ovalbumin (OVA) to induce anaphylaxis edema (Fig. 3). Treatments at various doses of Jamun extract was found to reduce the edema; no significant difference was found between the different doses used (Table 1). The treatment of rats with C48/80 released histamine in peritoneal mast cells, whereas pretreatment with Jamun leaf extract $(1 \mu \mathrm{g} / \mathrm{mL})$ inhibited this allergic reaction in the mast cells. Administration of OVA to BALBc mice induced substantial accumulation of leukocytes, mononuclear cells and eosinophils in the pleural cavity, whereas pretreatment of these mice with Jamun leaf extract at $1 \mathrm{~h}$ before the OVA administration significantly suppressed the accumulation of eosinophils in the pleural cavity, indicating its anti-inflammatory action. ${ }^{63}$ Moreover, study of the antiallergic effects of aqueous, methanol and methanol fraction of the aqueous extract of Jamun roots revealed that these extracts suppressed clonidine-induced catalepsy in mice by inhibiting the release of histamine triggered by mast cell degranulation. Finally, the administration of different root extracts of Jamun was shown to suppress milk-induced eosinophilia in mice. ${ }^{64}$

\section{Hepatoprotective activity}

Administration of aqueous leaf extract of Jamun to albino rats for 7 days prior to carbon tetrachloride treatment has been found to be hepatoprotective (Table $2^{30,35,66-77}$ ), as indicated by the alleviation of enhanced levels of aspartate aminotransferase and alanine aminotransferase compared to control rats treated with carbon tetrachloride alone. ${ }^{66}$ The fruit extract of Jamun has also been reported to protect rat hepatocytes against carbon tetrachloride-induced tox- icity in vitro. ${ }^{30}$ Similarly, the administration of ethanol extract of Jamun fruit pulp for 8 consecutive days prior to paracetamol treatment has been shown to protect rats against paracetamol-induced hepatotoxicity. ${ }^{67}$ The Jamun fruit extract has also been found to reduce bile duct ligation-induced damage to hepatocytes, hepatic fibrosis and macrophage infiltration by reducing lipid peroxidation and mRNA expression of intracellular adhesion molecule (Icam-1) and Chemokine (C-X-C motif) ligand 2 ( $\mathrm{Cxcl} 2$ genes). The fruit pulp extract of Jamun was also shown to reduce NO production by suppressing iNOS transcription, as well as transcriptional activation of NF-kB. ${ }^{68}$ The aqueous seed extract has been found to protect against liver damage in streptozotocin-induced diabetic rats. ${ }^{78}$ In addition, rats administered with seed extract for 14 days prior to carbon tetrachloride administration were protected against the carbon tetrachloride-induced hepatotoxicity. ${ }^{69}$ The findings from all of the above studies indicate the hepatoprotective potential of Jamun (Fig. 3).

\section{Gastroprotective}

Tannins extracted from the stem bark of Jamun protect against gastric ulcers (Table 2) in Sprague-Dawley rats induced by oral administration of $\mathrm{HCl} /$ ethanol, as indicated by alleviated gastric mucosal damage, reduced free radicals and reduced ulceration of the gastric mucosa. ${ }^{70}$ In addition, the ethanol extract of Jamun seeds has been reported to reduce indomethacin- and ethanol-induced peptic ulcers and acid-pepsin output in the streptozotocin-induced diabetic rats. ${ }^{71,72}$

\section{Cardioprotective activity}

Cardiovascular disorders represent the number one killer disease in the world, and the different extracts of Jamun have been investigated in diverse preclinical models for their cardioprotective activity (Table 2). Methanol extract of Jamun seeds administered orally at $500 \mathrm{mg} / \mathrm{kg}$ daily for 30 days to isoproterenol-treated rats was able to protect against myocardial damage. ${ }^{73}$ The ethanol extract of Jamun seed powder administered to Wistar rats for subsequent 15 days at 1 hour before doxorubicin treatment, in a similar fashion, protected cardiac tissues against the doxorubicin-induced cardiotoxicity. ${ }^{74}$

A randomized, double-blind, placebo controlled clinical trial of 
Table 3. Antidaibetic and antihyperlipidemic effects of different extracts of Jamun, Syzygium cumini

\begin{tabular}{|c|c|c|c|c|c|}
\hline S. No. & Parts used & Extract type & Activity & Species & References \\
\hline \multirow[t]{4}{*}{1.} & Seed & Aqueous & Antidiabetic & $\begin{array}{l}\text { Rabbits } \\
\text { Rat }\end{array}$ & $\begin{array}{l}{[80]} \\
{[81-87]}\end{array}$ \\
\hline & & Powder & & $\begin{array}{l}\text { Rat } \\
\text { Human } \\
\text { Mice }\end{array}$ & $\begin{array}{l}{[92,98,99]} \\
{[75,101]} \\
{[88,100]}\end{array}$ \\
\hline & & Ethanol & & $\begin{array}{l}\text { Rat and Rabbit } \\
\text { Rat }\end{array}$ & $\begin{array}{l}{[89,90,93]} \\
{[71,72]}\end{array}$ \\
\hline & & $\begin{array}{l}\text { Ethyl acetate } \\
\text { Methanol }\end{array}$ & & Rat & $\begin{array}{l}{[58]} \\
{[58,73,99]}\end{array}$ \\
\hline 2. & Stem & Ethanol & & Rats & {$[85,86,99]$} \\
\hline \multirow[t]{2}{*}{3.} & Fruit pulp & Lyophilized & & Rat & [93] \\
\hline & & $\begin{array}{l}\text { Aqueous } \\
\text { Ethanol }\end{array}$ & & Rat & {$[94,96]$} \\
\hline 4. & Leaf & Aqueous & & $\begin{array}{l}\text { Humans } \\
\text { Rat }\end{array}$ & $\begin{array}{l}{[95]} \\
{[99]}\end{array}$ \\
\hline \multirow[t]{2}{*}{5.} & Seed & Aqueous & Hyperlipidemia & Rabbit & [89] \\
\hline & & Ethanol & & $\begin{array}{l}\text { Rat } \\
\text { Mice }\end{array}$ & $\begin{array}{l}{[91,96-98,100,102]} \\
{[100]}\end{array}$ \\
\hline \multirow[t]{2}{*}{6.} & Fruit & Aquoeus & & Rat & {$[96]$} \\
\hline & & Ethanol & & Rat & [102] \\
\hline
\end{tabular}

99 diabetic patients given $5 \mathrm{~g}$ of seed powder before meals twice daily for 90 days has been reported, and the results indicate the powder lowered blood pressure and exerted a hypoglycemic action. ${ }^{75}$ The methanol seed extract of Jamun has also been found to protect $\mathrm{H} 9 \mathrm{C} 2$ cardiomyoblasts against glucose-induced stress. ${ }^{35,76}$ The hydroalcoholic extract of Jamun leaves, orally administered at a dose of $0.5 \mathrm{~g}$ daily for 8 weeks to hypertensive rats, has been reported to reduce hypertension. ${ }^{77}$ These collective preclinical and clinical model studies indicate that Jamun also acts as a cardioprotective agent (Fig. 3).

\section{Antidiabetic activity}

Diabetes afflicts a large number of the world's population, and Indians are especially prone to it. Despite the fact that this ailment was uncommon in ancient times, Ayurveda pharmacopeia mentions the antidiabetic effect of Jamun, whereby its seed powder is reported to control high blood sugar levels (Fig. 3). In the Western world, Jamun has been applied as a treatment to control blood sugar levels for more than 130 years now; however, clinical studies have shown mixed results. While some patients responded well, others did not respond to the treatment at all. ${ }^{79}$ The antidiabetic activity of Jamun has also been investigated in several preclinical animal models, which have demonstrated hypoglycemic effects for the different parts of Jamun (Table $3^{58,71-73,75,80-102}$ ).

In the twentieth century, a report was published citing no evidence of any reduction in blood sugar levels in alloxan-induced diabetic rats fed with Jamun seed extract. ${ }^{103}$ Thereafter, numerous reports were published in which various animal models showed evidence of Jamun reducing blood sugar levels. The ethanol extract of Jamun seed was reported to reduce blood glucose levels in streptozotocin-induced diabetes in rats ${ }^{71,72}$; and, the methanol extract of Jamun seeds was reported to reduce serum glucose level in the alloxan-induced diabetes in rats. ${ }^{75}$ The aqueous seed extract of Jamun has been reported to reduce blood glucose level in both diabetic rabbits and rats. ${ }^{80-84}$ The isolated compound mycaminose and ethyl acetate and methanol extracts of Jamun seeds also reduced blood glucose level in the streptozotocin-induced diabetic rats. ${ }^{58}$

The stem bark extract of Jamun was also found to decrease blood glucose levels in spontaneous diabetic rats. ${ }^{85,86}$ The aqueous lyophilized seed powder was effective in lowering the blood glucose level in both diabetic mice and rats. ${ }^{87,88}$ Interestingly, the water soluble seed extract containing gummy fibers was effective in controlling diabetes in alloxan-induced diabetes in rats, whereas the aqueous extract without gummy fiber was completely ineffective. ${ }^{104}$ The ethanol extract of Jamun seeds has been shown to reduce fasting blood glucose levels in the alloxan or streptozotocininduced diabetes in rats and rabbits. ${ }^{89}$

Similarly, the ethanol extract of seed kernel depleted levels of blood glucose, urea and cholesterol, increased glucose tolerance and reduced the glutamate oxaloacetate transaminase and glutamate pyruvate transaminase, and it also restored the activities of superoxide dismutase (SOD), catalase and glutathione peroxidase enzymes, and reduced glutathione (GSH) contents in liver and kidney of streptozotocin-induced diabetic rats. ${ }^{90,91}$ Streptozotocininduced rats fed with different doses of Jamun seed powder have shown a reduced fasting glucose level, indicating that the administration of Jamun seed powder was highly effective in controlling diabetes. ${ }^{92}$ However, in a Brazilian study, treatment of streptozotocin-induced diabetic rats with the lyophilized fruit pulp extract of Jamun was unable to reduce the raised blood sugar levels. ${ }^{93}$

The effect of aqueous and ethanol extracts of Jamun fruit pulp was studied in the alloxan-induced diabetic rats and both extracts 
were found to alleviate the blood glucose level, but the aqueous extract was more potent than the ethanol extract. ${ }^{94}$ Aqueous leaf extract of Jamun has also been reported to reduce the glucose levels, as well as the adenosine deaminase levels, in the serum of diabetic patients. ${ }^{95}$ The aqueous extract of the Jamun fruit pulp has been reported to reduce serum glucose level in streptozotocininduced diabetes in female Wistar rats; however, the combination of Jamun fruit extract with the stem bark extract of Cinnamon zeylanicum was more effective than the either treatment alone. ${ }^{97}$ The active components isolated by sephadex gel chromatography from the ethanol fraction of Jamun seed extract have been shown to reduce glucose level in the serum of alloxan-induced mild and severe diabetes in rats. ${ }^{97}$ Moreover, treatment of streptozotocin-induced type-II diabetic rats with $400 \mathrm{mg} / \mathrm{kg}$ aqueous seed extract of Jamun brought the glucose level to near normal and also increased the expression of PPAR $\gamma$ and PPAR $\alpha$ proteins in the rat liver. ${ }^{98}$

The aqueous and methanol extracts of root, stem bark, leaf and seed of Jamun have been reported to lower serum glucose levels in alloxan-induced diabetes in male Sprague-Dawley rats. ${ }^{99}$ The aqueous extract of Jamun seeds has also been reported to reduce serum glucose levels in alloxan-induced diabetes in mice. ${ }^{100} \mathrm{In}$ human diabetic subjects, supplementation of Jamun seed powder for 30 days reduced the fasting and post-prandial blood glucose levels. ${ }^{101}$ The results from these collective studies indicate that Jamun seeds possess the ability to control blood sugar in the diabetic condition (Table 3).

\section{Antihyperlipidemic activity}

Diabetes is often accompanied by hyperlipidemia, which results in cardiovascular morbidity, and different parts of Jamun have been investigated for cholesterol lowering activity (Fig. 3 and Table 3). The seed extract of Jamun has been reported to decrease total serum cholesterol:high-density lipoprotein (HDL) cholesterol ratio, serum low-density lipoprotein (LDL) cholesterol levels and to reduce the activity of HMG-CoA reductase in alloxan-induced diabetic rabbits. ${ }^{89}$ Jamun has both the ability to lower hyperglycemia as well as the enhanced lipid contents. The seed kernel ethanol extract of Jamun has been reported to reduce the LDL and very low-density lipoprotein cholesterol levels in streptozotocininduced diabetic rats; whereas, HDL cholesterol was increased, indicating that Jamun seed extract possesses antihyperlipidemic activity. ${ }^{92}$

The aqueous fruit pulp extract of Jamun has been found to alleviate enhanced triglycerides and total cholesterol, and to increase HDL cholesterol in the streptozotocin-induced diabetic rats. ${ }^{96}$ Likewise, the active components separated by sephadex gel chromatography from the ethanol seed extract fraction of Jamun have been reported to alleviate enhanced triglycerides and total cholesterol, and to increase HDL cholesterol in alloxan-induced diabetic rats. ${ }^{97}$ Aqueous seed extract of Jamun reduced the hyperlipidemic effect in alloxan-treated mice, by alleviating the enhanced levels of triglycerides, increasing the HDL cholesterol level, and returning the total cholesterol to normal. ${ }^{100}$ Finally, the ethanol extracts of seeds and fruits of Jamun have been reported to decrease the enhanced levels of triglycerides and LDL and to increase the HDL cholesterol level in rats fed with a high cholesterol diet. ${ }^{102}$

\section{Radioprotective Activity}

Every human and animal is exposed to ionizing radiation in daily life, from cosmic sources, air and space travel and diagnostic or medical treatment. Ionizing radiation is harmful and poses various threats to health, such as induction of cardiovascular, pulmonary, liver, kidney and reproductive disorders and cancer. This necessitates the search for pharmacological agents that can protect against the deleterious effects of ionizing radiation.

The radioprotective activity of Jamun leaf and seed extracts (Fig. 3) was evaluated by Jagetia and coworkers as early as $2002 .{ }^{105}$ The authors treated human peripheral blood lymphocytes with different concentrations of 1:1 DCM-MET) leaf extract before exposure to 3 Gy $\gamma$-radiation, and found protection by reduction of DNA damage as micronuclei that occurred in a concentration-dependent manner. Later on, a study of this extract was conducted to test the radioprotective effect in vivo, wherein mice were administered 5, $10,20,30,40,50,60$ and $80 \mathrm{mg} / \mathrm{kg}$ bodyweight of DCM-MET leaf extract. The administration of different doses of DCM-MET leaf extract protected the mice against radiation-induced mortality and sickness in a dose-dependent manner, and the optimum protective dose was found to be $30 \mathrm{mg} / \mathrm{kg} .{ }^{106}$ Studies were also undertaken to investigate the radioprotective effect of different doses of hydroalcoholic seed extract in mice exposed to a lethal dose (10 Gy), and it was found that the seed extract protected mice against radiationinduced sickness and mortality. Further studies with the optimum dose of $80 \mathrm{mg} / \mathrm{kg}$ seed extract resulted in a dose reduction factor of $1.24 .{ }^{107}$

The effect of DCM-MET leaf extract was studied on the intestines of mice treated with $5,10,20,30,40,50,60$ and $80 \mathrm{mg} /$ $\mathrm{kg}$ bodyweight DCM-MET leaf extract before exposure to different doses of $\gamma$-radiation. The mice receiving Jamun leaf extract showed increased villus height and a rise in the number of regenerating crypts, accompanied by a reduced number of goblet and dead cells; this indicated that Jamun extract protected mouse intestine and may have increased the life span of the irradiated mice. ${ }^{108}$ The effect of Jamun leaf extract on radiation-induced DNA damage was also studied; mice were administered with $50 \mathrm{mg} / \mathrm{kg}$ bodyweight of 1:1 DCM-MET leaf extract before exposure to different doses of $\gamma$-radiation. The cells from the irradiated animal spleens were extracted and cultured, and the DNA damage was estimated in cytochalasin B-blocked binucleate splenocytes. The Jamun leaf extract inhibited the production of radiation-induced micronuclei formation and thus protected the mice against radiation-induced DNA damage. ${ }^{43}$

The latest studies carried out in mice to understand the mechanism of action of radioprotection utilized $50 \mathrm{mg} / \mathrm{kg}$ bodyweight of DCM-MET Jamun leaf extract before exposure to $0,0.5,1,2$, 3 or 4 Gy whole body $\gamma$-radiation. The assays for GSH, catalase and SOD revealed that the activities of each were increased significantly in the Jamun leaf extract-treated group, at all exposure doses, compared to the irradiated control group, whereas the induction of lipid peroxidation was reduced in the mouse liver. ${ }^{109}$ All these studies have demonstrated that Jamun protects against the radiation-induced mortality, sickness, and intestinal and DNA damage by reducing radiation-induced free radicals and increasing various antioxidants (Fig. 3). Jamun also suppressed inflammatory cytokines, such as NF- $\mathrm{kB}$, iNOS, TNF- $\alpha$ and COX enzymes, ${ }^{45}$ which are elevated after exposure to ionizing radiation and may contribute to the radioprotective action (Table $4^{43,105-114}$ ).

\section{Anticancer activity}

Cancer is a non-communicable killer disease, which is second only to cardiovascular disease as far as causes of human mortality are 
Table 4. The radioprotective and antineoplastic activities of Jamun, Syzygium cumini in vivo and in vitro

\begin{tabular}{llllll}
\hline S. No. & Parts used & Extract type & Activity & Species & References \\
\hline 1. & Leaf & Dichloromethane and methanol (1:1) & Radioprotection & Human Lymphocytes & {$[105]$} \\
& & & & Mice & {$[43,106,108,109]$} \\
2. & Seed & Hydroalcoholic & & Mice & {$[107]$} \\
3. & Fruit skin & Crude & Anticancer & HeLa; SiHa & {$[110]$} \\
4. & Fruit pulp & Lyophilized & & MCF-7 & {$[111]$} \\
& & & & MDA-MB-231 & {$[114]$} \\
5. & Fruit & Methanol & H460 & {$[113]$} \\
& & Acidified methanol & HCT-116 & {$[112]$} \\
\end{tabular}

concerned. Cancer is treated by surgery, radiotherapy or chemotherapy or a combination of each (or all). In advanced stages, chemotherapy is the only remedy to treat cancer and, hence, it has emerged as one of the most important modalities of cancer treatment.

The majority of cancer treatment drugs $(47 \%)$ have been derived from natural resources or they are their semisynthetic derivatives. ${ }^{115}$ Different parts of Jamun have been investigated for cytotoxic action in vitro using a wide array of different cell lines (Fig. 3). The cytotoxic effect of Jamun fruit skin crude extract was studied in HeLa (HPV-18 positive) cells and $\mathrm{SiHa}$ (HPV-16 positive) cells by MTT assay, and the crude extract was found to trigger a cytotoxic effect on both the cell types (Table 4). The effect was more pronounced on the HeLa cells than on the SiHa cells, though. Similarly, the effect of 50\% methanol extract showed greater apoptosis in HeLa than SiHa cells. ${ }^{110}$

Freeze-dried Jamun fruit pulp extract was found to inhibit cell proliferation and growth of MCF-7 cells and MDA-MB-231 breast cancer cells in a concentration- and time-dependent manner; however, it was less effective in the MCF-10A cells. Yet, the Jamun extract did not induce apoptosis in untransformed MCF-10A breast cancer cells, whereas it was quite effective in triggering apoptotic cell death in both MCF-7 cells and MDA-MB-231 breast cancer cells. ${ }^{111}$ The ethyl acetate and methanol extracts of Jamun seeds reduced the cell survival and increased the cytotoxicity in MCF-7 cells in a concentration-dependent manner, and ethyl acetate extract was slightly better than the methanol extract. Almost similar results were reported for DNA fragmentation, an indicator of apoptosis. ${ }^{112}$

Jamun fruit extract has also been reported to induce a cytotoxic effect in a concentration-dependent manner in HCT-116 colon cancer cells. Moreover, the Jamun fruit extract induced apoptosis in HCT-116 and colon cancer stem cells by triggering DNA fragmentation, as determined by TUNEL assay and caspase $3 / 7$ activity. ${ }^{113}$ The methanol extract of Jamun fruit has been found to increase the cytotoxicity and suppress cell proliferation in H460 lung cancer cells in a concentration-dependent manner, with an IC50 of 35.2 $\mu \mathrm{g} / \mathrm{mL} .^{114}$

Apart from the above-listed activities, Jamun has shown several other properties in different experimental systems, including improvement of memory, antiarthritic activity, anti-nociceptive activity, antigenotoxic effect, central nervous system depressant activity, positive ionotropic effect, antispasmodic activity and many more that are not included in this review. ${ }^{116-121}$

The exact mechanism of action of Jamun in protecting against various disorders is not clearly understood. It seems that Jamun utilizes multiple pathways to exert its conducive effect on different ailments (Fig. 4). Free radical induction has been indicated in several disease processes and the neutralization of excess free radicals by Jamun may be one of the important mechanisms of its action, which is in line with reports of its ability to scavenge different free radicals. Jamun also stimulates the activation of different enzymes, like catalase, glutathione peroxidase, glutathione-s-transferase and $\mathrm{SOD}$, and increases synthesis of GSH, which may have helped in various ways to counter the free radical production, thereby helping to resolve the different diseases.

The reduction of lipid peroxidation may be another reason for its protective effect against several diseases. At the molecular level the presence of Jamun may have inhibited activation of transcription factors, including NF- $\kappa \mathrm{B}$, iNOS, TNF- $\alpha$ and COXs, causing reduced inflammation and protection against various health disorders. Apart from this, Jamun may have also up-regulated the transcription of PPAR $\alpha$ and PPAR $\gamma$, and Nrf2, leading to an increase in the antioxidant status.

\section{Conclusions}

The Jamun (Syzygium cumini) belonging to family Myrtaceae has been used in traditional medicine for treatment of different ailments, including diabetes. Phytochemical evaluation has shown that Jamun contains alkaloids, anthroquinone glycosides, flavonoids, tannins, saponins, phenols, cardiac glycosides, terpenoids, phytosterols, steroids and amino acids. Several individual components of these phytochemicals have been isolated, as well. Preclinical evaluation has shown that Jamun possesses several medicinal activities, including antioxidant, antibacterial, antifungal, antiallergic, antiinflammatory, antidiabetic antihyperlipidemic, gastroprotective, cardioprotective, hepatoprotective, anticancer, and radioprotective.

Despite the above-listed beneficial and medicinal effects, however, Jamun has some adverse effects in humans. It lowers blood sugar; therefore, it should not be taken at 1 week before, or at a minimum of 2 weeks after, surgery. Jamun should not be taken after drinking of milk and it should be avoided on an empty stomach. Breastfeeding mothers and pregnant women should avoid eating Jamun. Eating excessive amounts of Jamun may cause coughing, sputum accumulation in the lungs, body aches and fever.

The putative mechanisms of action of Jamun may be the scavenging of free radicals, as indicated by increased oxidative stress, elevated activities of catalase, glutathione peroxidase, glutathione- 


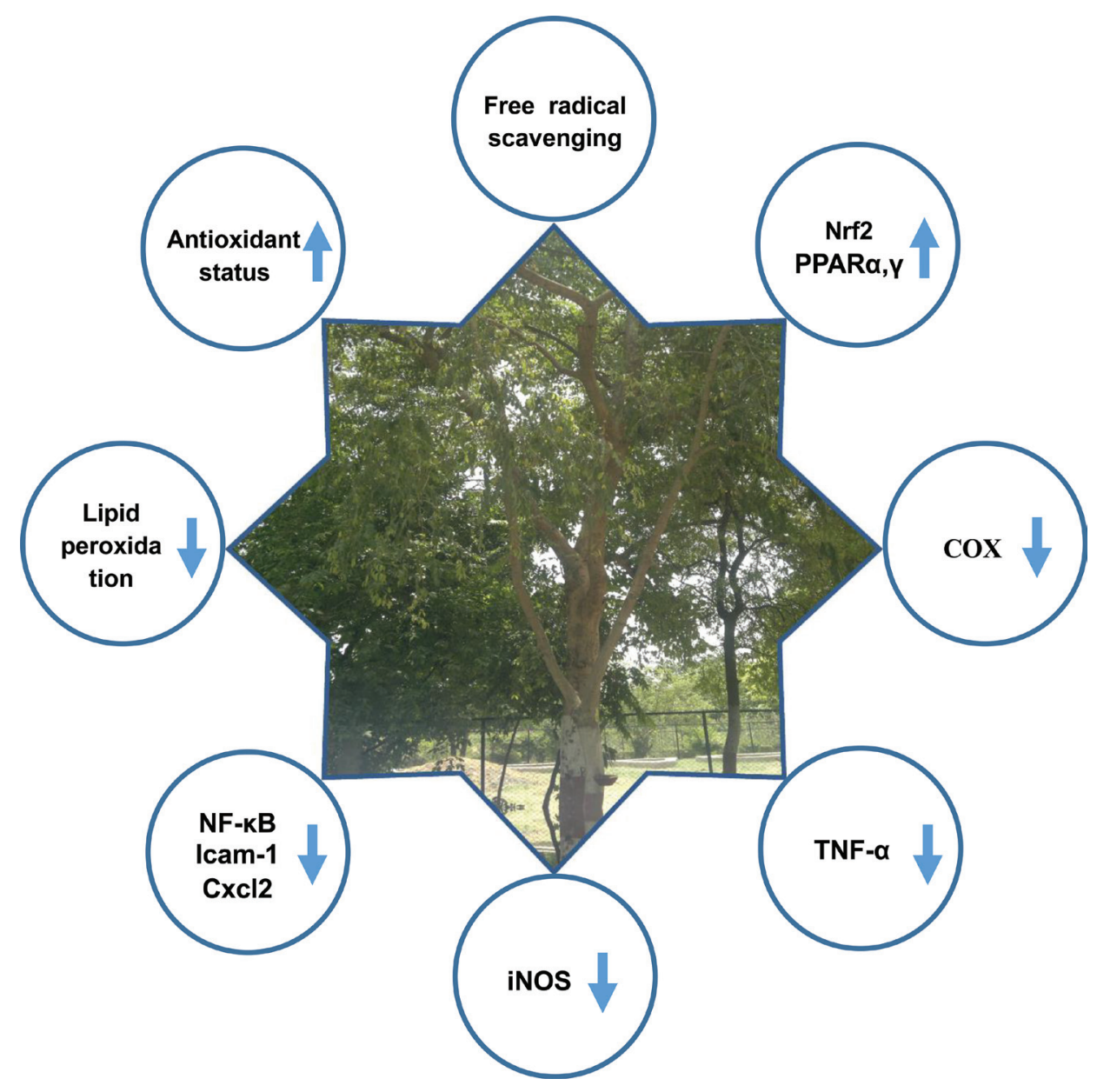

Fig. 4. Plausible mechanism of action of Jamum, Syzygium cumini.

s-transferase and SOD, and increased synthesis of GSH coupled with reduced lipid peroxidation. At the molecular level, Jamun may act through its inhibition of transcription of NF- $\mathrm{B}$, PPAR $\alpha$ and $\gamma$, COX, iNOS, TNF- $\alpha$ and other inflammatory cytokines, followed by the up-regulation of PPAR $\alpha$ and PPAR $\gamma$, and Nrf2. However, there is need to systematically evaluate the molecular mechanisms of action of Jamun in various study systems.

It is very clear from the collective literature that Jamun has several medicinal properties, and its full potential to treat some of the important disorders of the modern world needs to be further explored. Despite the plethora of studies that indicate its antidiabetic potential, its clinical success seems to be a far cry. Although Jamun fruits are consumed, the toxic implications of Jamun need to be systematically determined in combination with other pharmacologic agents, which will help in realizing its full clinical potential. Finally, the teratogenic effects of Jamun have not been studied, which also indicates the need to thoroughly investigate this aspect in the near future.

\section{Acknowledgments}

The author would like to thank the Indian Council of Medical Research, Department of Biotechnology, University Grants Commission, Government of India, New Delhi for financial assistance.

\section{Conflict of interest}

The author has no conflict of interest related to this publication.

Author contributions

This manuscript has been solely prepared by GCJ.

\section{References}

[1] Morton J. Jambolan. In: Morton JF (Ed) Fruits of warm climates. 1987;375-378.

[2] AP Benthall. Trees of calcutta and its neighborhood. Thacker, Spink \& Co. Ltd., Calcutta. 1946.

[3] Dastur JF. Useful plants of India and Pakistan. 2nd ed. D. B. Taraporevala Sons \& Co. Ltd., Bombay. 1951.

[4] Steinmetz EF. A botanical drug from the tropics used in the treatment of diabetes mellitus. Acta Phytotherapeut 1960;7(2):23-25.

[5] Reynertson K, Basile A, Kennelly MJ. Antioxidant potential of seven mystaceous fruits. Ethnobot Res Applicat 2005;3:25-35.

[6] Jain SK. Dictonary of Indian Folk medicine and ethnobotany. Deep Publications Paschimvihar, New Delhi, 1991.

[7] Swami SB, Thakor N S J, Patil MM, Haldankar PM. Jamun (Syzygium cumini (L.)): A review of its food and medicinal uses. Food Nutr Sci 
2012;3(8):1100-1117. doi:10.4236/fns.2012.38146.

[8] Bhowmik D, Gopinath H, Kumar BP, Duraivel S, Aravind G, Kumar KPS. Traditional and medicinal uses of Indian black berry. J Pharmacog Phytochem 2013;1(5):36-41.

[9] Lal BN, Choudhuri KD. Observations on Momordica charantia Linn, and Eugenia jambolana Lam as oral antidiabetic remedies. Indian J Med Res 1968;2:161-164.

[10] Ayyanar M, Subash-Babu P. Syzygium cumini (L.) Skeels: a review of its phytochemical constituents and traditional uses. Asian Pacific J Trop Biomed 2012;2(3):240-246. doi:10.1016/S22211691(12)60050-1.

[11] Gordon A, Jungfer E, da Silva BA, Maia JG, Marx F. Phenolic constituents and antioxidant capacity of four underutilized fruits from the Amazon region. J Agr Food Chem 2011;59:7688-7699. doi:10.1021/ jf201039r.

[12] Burkill H. A dictionary of the economic products of the Malay Peninsula. Vol. 1, Crown Agents for the Colonies, London, 1935.

[13] Quisumbing E. Medicinal plants of the Philippines. Department of Agriculture and Natural Resource, Manila, 1951.

[14] Damasceno DC, Volpato GT, Calderon ID, Rudge CVC. Study of Averrhoa carambola and Eugenia jambolana extracts purchased from manipulation drug store on the experimental diabetes. Rev Brasil de Toxicol 2002;15(1):9-14.

[15] Ranjan A, Jaiswal RA, Raja RB. Enhancement of Syzygium cumini (Indian Jamun) active constituents by ultra-violet (UV) irradiation method. Scientific Res Essays 2011;6(12):2457-2464. doi:10.5897/ SRE10.977.

[16] Gowri SS, Vasantha K. Phytochemical screening and antibacterial activity of Syzygium cumini (L.) (Myrtaceae) leaves extracts. Int J PharmTech Res 2010;2(2):1569-1573.

[17] Kalakoti M, Kumar A. Phytochemical and antioxidant screening of leaf extract of Syzygium cumini. Int J Adv Res 2015;3(1):371-378.

[18] Gopinath SM, Rakesh CK, Patil GMA, Dayananda KS. Preliminary phytochemical evaluation of leaf extracts of Euphorbia hirta, Syzygium cumini of Siddarabetta, Tumkur district, Karnataka. Int J Pharma Biosci 2012;3(2):431-435.

[19] Kamal A. Phytochemical screening of Syzygium cumini seeds. Ind J Plant Sci 2014;3(4):1-4.

[20] Satyavathi C, Bhavani NL. Evaluation of phytochemical constituents and antibacterial activity in leaf extracts of Syzygium cumini L. World J Phramaceut Res. 2014;3(10):768-776.

[21] Mubassara S, Biswas KK, Hasan MM, Hossain MI, Paul S. In vitro phytochemical, antibacterial and antioxidant analyses in different plant parts of Syzium cumini. Int J Pharmacog Phytochem Res 2015;7(1):150-155.

[22] Rastogi RM, Mehrotra BN. Compendium of Indian medicinal plants. Lucknow India: Central Drug Research Institute 1990;1:388-389.

[23] Mahmoud II, Marzouk MS, Moharram FA, El-Gindi MR, Hassan AM. Acylated flavonol glycosides from Eugenia jambolana leaves. Phytochemistry 2001;58(8):1239-1244. doi:10.1016/S00319422(01)00365-X.

[24] Gupta GS, Sharma DP. Triterpenoid and other constituents of Eugenia jambolana leaves. Phytochemistry 1974;13:2013-2014.

[25] Kumar A, Jayachandran T, Aravindan P, Deecaraman D, Ilavarasan $\mathrm{R}$, Padmanabhan N. Neutral components in the leaves and seeds of Syzygium cumini. African J Pharm Pharmacol 2009;3(11):560-561.

[26] Shafi PM, Rosamma MK, Jamil K, Reddy PS. Antibacterial activity of Syzygium cumini and Syzygium tra_ancoricum leaf essential oils. Fitoterapia 2002;73(5):414-416. doi:10.1016/S0367326X(02)00131-4.

[27] Elansary HO, Salem MZM, Ashmawy NA, Yacout MM. Chemical composition, antibacterial and antioxidant activities of leaves essential oils from Syzygium cumini L., Cupressus sempervirens L. and Lantana camara L. from Egypt. J Agr Sci 2012;4(10):144-152. doi:10.5539/jas.v4n10p144.

[28] Nishandhini S, Sudha V, Mallavarapu GR, Murugan R. Chemical compositions, $\alpha$-amylase inhibitory and antioxidant activities of the essential oils from unripe fruit pulp and leaves of Syzygium cumini. Int J Pharm Pharm Sci 2015;7(2):511-514.

[29] Nair RAG, Subramanian SS. Chemical examination of the flowers of Eugenia jambolana. J Sci Ind Res 1962;21B:457-458.
[30] Veigas JM, Shrivasthava R, Neelwarne B. Efficient amelioration of carbon tetrachloride induced toxicity in isolated rat hepatocytes by Syzygium cumini Skeels extract. Toxicol in Vitro 2008;22(6):14401446. doi:10.1016/j.tiv.2008.04.015.

[31] Faria AF, Marques MC, Mercadante AZ. Identification of bioactive compounds from jambolão (Syzygium cumini) and antioxidant capacity evaluation in different $\mathrm{pH}$ conditions. Food Chem 2011;126:1571-1578. doi:10.1016/j.foodchem.2010.12.007.

[32] Santos DT, Cavalcanti RN, Rostagno MA, Queiroga CL, Eberlin $\mathrm{MN}$, Meireles MAA. Extraction of polyphenols and anthocyanins from the jambul (Syzygium cumini) Fruit Peels. Food Pub Health 2013;3(1):12-20. doi:10.5923/j.fph.20130301.02.

[33] Kaume L, Gilbert WC, Brownmiller C, Howard LR, Devareddy L. Cyanidin 3-O-b-D-glucoside-rich blackberries modulate hepatic gene expression, and anti-obesity effects in ovariectomized rats. J Funct Foods 2012;4:480-488. doi:10.1016/j.jff.2012.02.008.

[34] Sapana SK, Jadhav VM, Kadam VJ. Development and validation of HPTLC method for determination of 3-hydroxy androstane [16,17C] (6'methyl, 2'-1-hydroxy-isopropene-1-yl) 4,5,6 H pyran in Jambul seed (Syzygium cumini). Int J PharmTech Res 2009;1(4):1129-1135.

[35] Atale N, Chakraborty M, Mohanty S, Bhattacharya S, Nigam D, Sharma M, et al. Cardioprotective role of Syzygium cumini against glucose-induced oxidative stress in $\mathrm{H} 9 \mathrm{C} 2$ cardiac myocytes. Cardiovasc Toxicol 2013;13(3):278-289. doi:10.1007/s12012-013-9207-1.

[36] Sengupta P, Das PB. Terpenoids and related compounds part IV triterpenoids the stem-bark of Eugenia jambolana Lam. Indian Chem Soc 1965;42:255-258.

[37] BhargavaKK, Dayal R, Seshadri TR. Chemical components of Eugenia jambolana stem bark. Curr Sci 1974;43:645-646.

[38] Bhatia IS, Bajaj KL. Chemical constituents of the seeds and bark of Syzygium cumini. Plant Med 1975;28(4):346-352. doi:10.1055 /s-0028-1097868.

[39] Kopanski L, Schnelle G. Isolation of bergenin from barks of Syzygium cumini. Plant Med 1988;54(6):572. doi:10.1055/s-2006-962577.

[40] Jagetia GC, Baliga MS. The evaluation of nitric oxide scavenging activity of certain Indian medicinal plants in vitro: a preliminary study. J Med Food 2004;7(3):343-348. doi:10.1089/jmf.2004.7.343.

[41] Banerjee A, Dasgupta N, De B. In vitro study of antioxidant activity of Syzygium cumini fruit. Food Chem 2005;90(4):727-733. doi:10.1016/j.foodchem.2004.04.033.

[42] Ruan ZP, Zhang LL, Lin YM. Evaluation of the antioxidant activity of Syzygium cumini leaves. Molecules 2008;13(10):2545-2555. doi:10.3390/molecules13102545.

[43] Jagetia GC, Shetty PC, Vidyasagar MS. Inhibition of radiation-induced DNA damage by Jamun, Syzygium cumini in the cultured splenocytes of mice exposed to different doses of $\gamma$-radiation. Integrat Cancer Ther 2012;11(2):141-153. doi:10.1177/1534735411413261.

[44] Aqil F, Gupta A, Munagala R, Jeyabalan J, Kausar H, Sharma RJ, et al. Antioxidant and antiproliferative activities of anthocyanin/ellagitannin-enriched extracts from Syzygium cumini L. ('Jamun', the Indian Blackberry). Nutr Cancer 2012;64(3):428-438. doi:10.1080/016355 81.2012.657766.

[45] Chanudom L, Tangpong J. Anti-inflammation property of Syzygium cumini (L.) Skeels on Indomethacin-induced acute gastric ulceration. Gastroenterol Res Pract 2015;2015:343642. doi:10.1155/2015/343642.

[46] Mohamed AA, Ali SI, El-Baz FK. Antioxidant and antibacterial activities of crude extracts and essential oils of Syzygium cumini leaves. PLoS One 2013;8(4):e60269. doi:10.1371/journal.pone.0060269.

[47] Eshwarappa RS, Iyer RS, Subbaramaiah SR, Richard SA, Dhananjaya BL. Antioxidant activity of Syzygium cumini leaf gall extracts. Biolmpacts 2014;4(2):101-107. doi:10.5681/bi.2014.018.

[48] Margaret E, Shailaja AM, Rao VV. Evaluation of antioxidant activity in different parts of Syzygium cumini (Linn.). Int J Curr Microbiol App Sci 2015;4(9):372-379.

[49] de Oliveira GF, Furtado NAJC, Filho AAS, Martins CHG, Bastos JK, Cunha WR, et al. Antimicrobial activity of Syzygium cumini (myrtaceae) leaves extract. Brazilian J Microbiol 2007;38(2):381-384. doi:10.1590/S1517-83822007000200035.

[50] Patel PR, Rao TVR. Antibacterial activity of underutilized fruits of Jamun (Syzygium cumini L. Skeels). Int J Curr Pharm Res 2011;4(1):36- 
39.

[51] Ahsan N, Paul N, Islam N, Akhand AA. Leaf extract of Syzygium cumini shows anti-Vibrio activity involving DNA damage. Dhaka Univ J Pharm Sci 2012;11(1):25-28.

[52] Meshram GA, Yadav SS, Shinde D, Patil B, Singh D. Antibacterial study and effect of ethanolic extracts of Syzygium cumini seeds powder on Glucoamylase in vitro. J Pharm Sci Res 2011;3(2):1060-1063.

[53] Pareek A, Meena RK, Yadav B. Antimicrobial activity of Syzygium cumini. Ind J Appl Res 2015;5(9):64-66.

[54] Mueller M, Janngeon K, Puttipan R, Unger FM, Viernstein H, Okonogi S. Anti-inflammatory, antibacterial, and antioxidant activities of Thai medicinal plants. Int J Pharm Pharm Sci 2015;7(11):123-128.

[55] Chaudhuri AKN, Pal S, Gomes A, Bhattacharya S. Anti-inflammatory and related action of Syzygium cumini seed extract. Phytotherapy Res 1990;4:5-10. doi:10.1002/ptr.2650040103.

[56] Ezekiel U, Heuertz R. Anti-Inflammatory Effect of Syzygium cumini on chemotaxis of human neutrophils. Int J Pharmacog Phytochem Res 2015;7(4):714-717.

[57] Muruganandan S, Srinivasan K, Chandra S, Tandan SK, Lal J, Raviprakash V. Anti-inflammatory activity of Syzygium cumini bark. Fitoterapia 2001;72:369-375. doi:10.1016/S0367-326X(00)00325-7.

[58] Kumar A, llavarasan R, Jayachandran T, M Deecaraman, RM Kumar, P Aravindan, et al. Antiinflammatory activity of Syzygium cumini seed. Afr J Biotechnol 2008;7(8):941-943.

[59] Roy A, Bhattacharya S, Pandey JN, Biswas M. Anti-inflammatory activity of Syzygium cumini leaf against experimentally induced acute and chronic inflammations in rodents. Alternat Med Stud 2011;1(1):23-25. doi:10.4081/ams.2011.e6.

[60] Siani AC, Souza MC, Henriques MGMO, Ramos MFS. Anti-inflammatory activity of essential oils from Syzygium cumini and Psidium guajava. Pharm Biol 2013;51(7):881-887. doi:10.3109/13880209.2 013.768675.

[61] Machado RRP, Jardim DF, Souza AR, Scion E, Fabri RL, Carpanez AG, et al. The effect of essential oil of Syzygium cumini on the development of granulomatous inflammation in mice. Braz J Pharmacogn 2013;23(3):488-496. doi:10.1590/\$0102-695X2013005000030.

[62] Gupta A, Chaphalkar SR. Anti-inflammatory activity of flavonoids from medicinal plants against hepatitis $B$ vaccine antigen on human peripheral blood mononuclear cells. Asian J Med Pharm Sci 2015;3(1):728-732.

[63] Brito FA, Lima LA, Ramos MFS, Nakamura MJ, Cavalher-Machado SC, Siani AC, et al. Pharmacological study of anti-allergic activity of Syzygium cumini (L.) Skeels. Braz J Med Biol Res 2007;40(1):105115. doi:10.1590/S0100-879X2007000100014.

[64] Balakrishna GV, Sowmya K, Bollapalli VR, Rao MVR. Anti-allergic studies of Albizzia Lebbeck and Syzygium Cumini (L- Syzygium gambolana). J Micbiol Bitechnol 2016;1(1):000103.

[65] Bitencourt PER, Cargnelutti LO, Stein CS, Lautenchleger R, Ferreira LM, Sangoi M, et al. Anti-inflammatory action of seed extract and polymeric nanoparticles of Syzygium cumini in diabetic rats infected with Candida albicans. J Appl Pharmaceut Sci 2017;7(1):007-016. doi:10.7324/JAPS.2017.70102.

[66] Moresco RN, Sperotto RL, Bernardi AS, Cardoso RF, Gomes P. Effect of the aqueous extract of Syzygium cumini on carbon tetrachlorideinduced hepatotoxicity in rats. Phytother Res 2007;21(8):793-795. doi:10.1002/ptr.2158.

[67] Das S, Sarma G. Study of the hepatoprotective activity of the ethanolic extract of the pulp of Eugenia jambolana (Jamun) in albino rats. J Clin Diag Res 2009;3(2):1466-1474.

[68] Donepudi AC, Aleksunes LM, Driscoll MV, Seeram NP, Slitt AL. The traditional Ayurvedic medicine, Eugenia jambolana (Jamun fruit), decreases liver inflammation, injury and fibrosis during cholestasis. Liver Int 2012;32(4):560-573. doi:10.1111/j.14783231.2011.02724.x.

[69] Islam M, Hussain K, Latif A, Hashmi FK, Saeed H, Bukhari NI, et al. Evaluation of extracts of seeds of Syzygium cumini L. for hepatoprotective activity using $\mathrm{CCl}$-induced stressed rats. Pak Vet J 2015;35(2):197-200.

[70] Ramirez RO, Roa CC Jr. The gastroprotective effect of tannins extracted from duhat (Syzygium cumini Skeels) bark on $\mathrm{HCl} /$ ethanol induced gastric mucosal injury in Sprague-Dawley rats. Clin Hemor- heol Microcirc 2003;29(3-4):253-261.

[71] Chaturvedi A, Bhawani G, Agarwal PK, Goel S, Singh A, Goel RK. Antidiabetic and antiulcer effects of extract of Eugenia jambolana seed in mild diabetic rats: study on gastric mucosal offensive acid-pepsin secretion. Indian J Physiol Pharmacol 2009;53(2):137-146.

[72] Jonnalagadda A, Maharaja KK, Prem Kumar N. Combined effect of Syzygium cumini seed kernel extract with oral hypoglycemics in diabetes induced increase in susceptibility to ulcerogenic stimuli. J Diabetes Metab 2013;4:236. doi:10.4172/2155-6156.1000236.

[73] Mastan SK, Latha TB, Latha TS, Srikanth A, Chaitanya G, Kumar KE. Influence of methanolic extract of Syzygium cumini seeds on the activity of gliclazide in normal and alloxan-induced diabetic rats. Pharmacologyonline 2009;3:845-850.

[74] Soncharan P, Shanmugarajan TS, Somasundaram I, Niladri M. Protective effect of Syzygium cumini seeds against doxorubicin induced cardiotoxicity in rats. Int J Pharm Life Sci 2010;1(6):343-349.

[75] Sidana S, Singh VB. Effect of Syzygium cumini (Jamun) seed powder on blood pressure in patients with type 2 diabetes mellitus - A double blind randomized control trial. Int J Scientific Res 2016;5(3):753755.

[76] Atale N, Rani V. Syzygium Cumini: An effective cardioprotective via its antiglycoxidation potential. Int J Pharm Sci Rev Res 2016;37(1):4251.

[77] Ribeiro RM, Pinheiro Neto VF, Ribeiro KS, Vieira DA, Abreu IC, Silva $\mathrm{SN}$, et al. Antihypertensive effect of Syzygium cumini in spontaneously hypertensive rats. Evid Based Complement Alternat Med 2014;2014:605452. doi:10.1155/2014/605452.

[78] SR Behera, M Sekkizhar, K Sarath Babu. Hepatoprotactive activity of aqueous extract of syzygium cumini seed on streptozotocin induced diabetes in rats. Int J Ayurved Herb Med 2014;4(2):1470-1477.

[79] Helmstädter A. Syzygium cumini (L.) SKEELS (Myrtaceae) against diabetes -125 years of research. Pharmazie 2008;63(2):91-101. doi:10.1691/ph.2008.7335.

[80] Brahmachari HD, Augusti KT. Hypoglycemic agents from Indian indigenous plants. J Pharm Pharmacol 1961;13:381-182. doi:10.1111/j.2042-7158.1961.tb11839.x.

[81] Kedar P, Chakrabarti CH. Effects of Jambolan seed treatment on blood sugar, lipids and urea in streptozotocin induced diabetes in rabbits. Ind J Physiol Pharmacol 1983;27(2):135-140.

[82] Nair BR, Santhakumari G. Anti-diabetic activity of the seed kernel of Syzygium cumini Linn. Ancient Sci Life 1986;6(2):80-84.

[83] Achrekar A, Kaklij GS, Pote MS, Kelkar SM. Hypoglycemic activity of Eugenia jambolana and Ficus bengalensis: mechanism of action. In Vivo 1991;5(2):143-147.

[84] Prince PS, Menon VP, Pari L. Hypoglycemic activity of Syzigium cumini seeds: effect on lipid peroxidation in alloxan diabetic rats. J Ethnopharmacol 1998;61(1):1-7. doi:10.1016/S0378-8741(98)000026.

[85] Chirvan-Nia MM, Ratsimamanga AR. Régression de la cataracte et de l'hyperglycénie chez le Rat de sable (Psammomys obesus) diabétique ayant recu un extrait de Eugenia jambolana (Lamarck). C R Acad Sci Hebd Seances Acad Sci D 1972;274:1514-1516.

[86] Ratsimamanga AR, Loiseau A, Ratsimamanga-Urveg S, Bibal-Prot P. Nouvelle contribution à l'étude de l'action d'un principe hypoglycé miant mis en évidence dans l'écorce jeune de Eugenia jambolana (Myrtacées) sur l'hyperglycémie provoquée du lapin mormal et poursuite de sa purification. C R Acad Sci Hebd Seances Acad Sci D 1973;277:2219-2222.

[87] Vikrant V, Grover JK, Tandon N, Rathi SS, Gupta N. Treatment with extracts of Momordica charantia and Eugenia jambolana prevents hyperglycemia and hyperinsulinemia in fructose fed rats. J Ethnopharmacol 2001;76(2):139-143. doi:10.1016/S0378-8741(01)002185.

[88] Grover JK, Vats V, Rathi SS, Dawar R. Traditional Indian anti-diabetic plants attenuate progression of renal damage in streptozotocin induced diabetic mice. J Ethnopharmacol 2001;76(3):233-238 doi:10.1016/S0378-8741(01)00246-X.

[89] Sharma SB, Nasir A, Prabhu KM, Murthy PS, Dev G. Hypoglycaemic and hypolipidemic effect of ethanolic extract of seeds of Eugenia jambolana in alloxan-induced diabetic rabbits. J Ethnopharmacol 2003;85:201-206. doi:10.1016/S0378-8741(02)00366-5. 
[90] Ravi K, Ramachandran B, Subramanian S. Protective effect of Eugenia jambolana seed kernel on tissue antioxidants in streptozotocin-induced diabetic rats. Biol Pharm Bull 2004;27(8):1212-1227. doi:10.1248/bpb.27.1212.

[91] Ravi K, Rajasekaran S, Subramanian S. Antihyperlipidemic effect of Eugenia jambolana seed kernel on streptozotocin-induced diabetes in rats. Food Chem Toxicol 2005;43(9):1433-1439. doi:10.1016/j. fct.2005.04.004.

[92] Sridhar SB, Sheetal UD, Pai MR, Shastri MS. Preclinical evaluation of the antidiabetic effect of Eugenia jambolana seed powder in streptozotocin-diabetic rats. Braz J Med Biol Res 2005;38(3):463-468. doi:10.1590/S0100-879X2005000300018.

[93] Pepato MT, Mori DM, Baviera AM, Harami JB, Vendramini RC, Brunetti IL. Fruit of the jambolan tree (Eugenia jambolana Lam.) and experimental diabetes. J Ethnopharmacol 2005;96(1-2):43-48. doi:10.1016/j.jep.2004.07.029.

[94] Sharma SB, Nasir A, Prabhu KM, Murthy PS. Antihyperglycemic effect of the fruit-pulp of Eugenia jambolana in experimental diabetes mellitus. J Ethnopharmacol 2006;104(3):367-373. doi:10.1016/j. jep.2005.10.033.

[95] Bopp A, De Bona KS, Bellé LP, Moresco RN, Moretto MB. Syzygium cumini inhibits adenosine deaminase activity and reduces glucose levels in hyperglycemic patients. Fundam Clin Pharmacol 2009;23(4):501-507. doi:10.1111/j.1472-8206.2009.00700.x.

[96] Rekha N, Balaji R, Deecaraman M. Antihyperglycemic and antihyperlipidemic effects of extracts of the pulp of Syzygium cumini and bark of Cinnamon zeylanicum in streptozotocin-induced diabetic rats. J Appl Biosci 2010;28:1718-1730.

[97] Sharma SB, Tanwar RS, Nasir A, Prabhu KM. Antihyperlipidemic effect of active principle isolated from seed of Eugenia jambolana on alloxan-induced diabetic rabbits. J Med Food 2011;14(4):353-359. doi:10.1089/jmf.2010.1227.

[98] Sharma AK, Bharti S, Kumar R, Krishnamurthy B, Bhatia J, Kumari S, et al. Syzygium cumini ameliorates insulin resistance and $\beta$-cell dysfunction via modulation of PPAR, dyslipidemia, oxidative stress, and TNF- $\alpha$ in type 2 diabetic rats. J Pharmacol Sci 2012;119(3):205-213. doi:10.1254/jphs.11184FP

[99] Deb L, Bhattacharjee C, Shetty SR, Dutta A. Evaluation of anti-diabetic potential of the Syzygium cumini (Linn) skeels by reverse pharmacological approaches. Bull Pharmaceut Res 2013;3(3):135-145.

[100] Siddiqui MS, Sharma B, Ram G. Anti-hyperglycemic and anti-hyperlipemia effects of Syzygium cumini seed in alloxan induced diabetes mellitus in Swiss albino mice (Mus musculus). Med Aromat Plants 2014;3(4):166. doi:10.4172/2167-0412.1000166.

[101] Ayya N, Nalwade V, Khan TN. Effect of Jamun (Syzygium cumini L.) seed powder supplementation on blood glucose level of type-II diabetic subject. Food Sci Res J 2015;6(2):353-356. doi:10.15740/HAS/ FSRJ/6.2/353-356

[102] Raza A, Malook S, Ali MUsman, Akram MN, Wazir I, Sharif MN. Antihyper-cholesterolemic role of ethanolic extract of Jamun (Syzygium cumini) fruit and seed in hypyercholesterolemic rats. American-Eurasian J Agric Environ Sci 2015;15(6):1012-1018. doi:10.5829/idosi. aejaes.2015.15.6.12678.

[103] Wastl H, Boericke GW, Foster WC. Studies of effects of Syzygium jambolanum on alloxan-diabetic rats. Arch Int Pharmacodyn Ther 1947;75:33-50.

[104] Pandey M, Khan A. Hypoglycaemic effect of defatted seeds and water soluble fibre from the seeds of Syzygium cumini (Linn.) skeels in alloxan diabetic rats. Indian J Exp Biol 2002;40:1178-1182.

[105] Jagetia GC, Baliga MS. Syzygium cumini (Jamun) reduces the radia- tion-induced DNA damage in the cultured human peripheral blood lymphocytes: a preliminary study. Toxicology Lett 2002;132(1):1925. doi:10.1016/S0378-4274(02)00032-2.

[106] Jagetia GC, Baliga MS. Evaluation of the radioprotective effect of the leaf extract of Syzygium cumini (Jamun) in mice exposed to a lethal dose of gamma-irradiation. Nahrung 2003;47(3):181-185. doi:10.1002/food.200390042.

[107] Jagetia GC, Baliga MS, Venkatesh P. Influence of seed extract of Syzygium cumini (Jamun) on mice exposed to different doses of Y-radiation. J Radiat Res 2005;46(1):59-65. doi:10.1269/jrr.46.59.

[108] Jagetia GC, Shetty PC, Vidyasagar MS. Treatment of mice with leaf extract of Jamun (Syzygium cumini Linn. Skeels) protects against the radiation-induced damage in the intestinal mucosa of mice exposed to different doses of $\gamma$-radiation. Pharmacologyonline 2008;1:169195.

[109] Jagetia GC, Shetty PC. Augmentation of antioxidant status in the liver of Swiss albino mice treated with Jamun (Syzygium cumini, Skeels) extract before whole body exposure to different doses of ү-Radiation. J Adv Res Biotech 2016;1(1):1-13.

[110] Barh D, Viswanathan G. Syzygium cumini inhibits growth and induces apoptosis in cervical cancer cell lines: A primary study. Ecancermedicalscience 2008;2:83. doi:10.3332/ecancer.2008.83.

[111] Li L, Adams LS, Chen S, Killian C, Ahmed A, Seeram NP. Eugenia jambolana Lam. berry extract inhibits growth and induces apoptosis of human breast cancer but not non- tumorigenic breast cells. J Agric Food Chem 2009;57(3):826-831. doi:10.1021/jf803407q.

[112] Ruthurusamy SK, Dheeba B, Hameed SS, Palanisamy S. Anti-cancer and anti-oxidative potential of Syzygium cumini against breast cancer cell lines. J Chem Pharmaceut Res 2015;7(10):449-460.

[113] Charepalli V, Reddivari L, Vadde Ramakrishna, Walia S, Radhakrishnan S, Vanamala JKP. Eugenia jambolana (Java Plum) fruit extract exhibits anti-cancer activity against early stage human HCT116 colon cancer cells and colon cancer stem cells. Cancers (Basel) 2016;8(3):pii:E29. doi:10.3390/cancers8030029.

[114] Tripathy G, Pradhan D, Pradhan S, Dasmohapatra T. Evaluation of plant extracts against lung cancer using $\mathrm{H} 460$ cell line. Asian J Pharm Clin Res 2016;9(2):227-229.

[115] Pan L, Chai H, Kinghorn AD. The continuing search for antitumor agents from higher plants. Phytochem Lett 2010;3(1):1-8. doi:10.1016/j.phytol.2009.11.005.

[116] Rahaman A, Hossain S, Rahman M, Hossain I, Nahar T, Uddin B, et al. Syzygium Cumini (L.) seed extract improves memory related learning ability of old rats in eight arm radial maze. J Pharmacog Phytochem 2013;1(6):85-94.

[117] Kumar EK, Mastan SK, Reddy KR, Reddy GA, Raghunandan N, Chaitanya G. Anti-arthritic property of methanolic extract of Syzygium cumini seeds. Int J Integr Biol 2008;4(1):55-61.

[118] Avila-Peña D, Peña N, Quintero L, Suárez-Roca H. Antinociceptive activity of Syzygium jambos leaves extract on rats. J Ethnopharmacol 2007;112(2):380-385. doi:10.1016/j.jep.2007.03.027.

[119] Arun R, Prakash MVD, Abraham SK, Premkumar K. Role of Syzygium cumini seed extract in the chemoprevention of in vivo genomic damage and oxidative stress. J Ethnopharmacol 2011;134(2):329 333. doi:10.1016/j.jep.2010.12.014.

[120] Archana N, Ramasamy M, Raj CD. Pharmacological screening of ethanolic extract of Syzygium cumini seed on isolated smooth muscle strip and heart. Int J Pharm Pharmaceut Sci 2012;4(2):108-110.

[121] Kumar A, Padmanabhan N, Krishnan MRV. Central nervous system activity of Syzygium cumini seed. Pakistan J Nutr 2007;6(6):698700 . 